\title{
The Global Financial Crisis and the Role of Ownership Structure on Cost of Capital
}

\author{
Salman Afkhami Rad \\ Department of Finance, Waikato Management School, The University of Waikato \\ Hamilton, New Zealand \\ Tel: 64-7838-4466_E-mail: sa177@waikato.ac.nz
}

Professor Stuart Locke

Dean of Finance department, Waikato Management School, The University of Waikato

Hamilton, New Zealand

Tel: 64-7838-4466 E-mail: smlocke@waikato.ac.nz

Dr. Krishna Reddy

Lecturer at Finance Department, Waikato Management School, The University of Waikato

Hamilton, New Zealand

Tel: 64-7838-4466Ｅ-mail: Krishna@waikato.ac.nz

Received: May 12, 2013 Accepted: May 30, 2013 Published: June 17, 2013

doi:10.5296/ajfa.v5i1.3687 URL: http://dx.doi.org/10.5296/ajfa.v5i1.3687

\begin{abstract}
This paper explores the relationship between ownership structure and cost of capital. Prior studies have established links between ownership structure, firm performance and cost of capital but their results are mixed and inconclusive. As ownership structure is one of the important issues faced by corporates, especially in listed companies, the objective of this study is to explore the relationship between ownership structure and cost of capital in listed companies. In addition, the role ownership structure plays is regarded as important; the expectation of managers and shareholders is to determine the optimal ownership structure that protects companies in normal and in crisis situations as well. Therefore, this study
\end{abstract}




\section{Macrothink}

Asian Journal of Finance \& Accounting

ISSN 1946-052X

2013, Vol. 5, No. 1

explores the role ownership structure plays in determining the cost of capital during and after the financial crisis period. After employing the panel regression method, we report a negative relationship between the ownership structure and cost of capital during a global financial crisis.

Keywords: Global financial crisis, Ownership structure, Cost of equity capital 


\section{Introduction}

Global financial markets regardless of their distance or openness, exogenously were affected by the global financial crisis in 2007 (Bedford, 2008). The effect of the crisis on cost of capital was different across countries. The World Bank (2010), reports that cost of risk in high-income countries fell more sharply during the crisis compared to other countries. Interest rates in developing countries fell substantially during the financial crisis, countries in East Asia and the Pacific region were also affected but developing countries in Europe and Central Asia were not.

A global financial crisis affects economies in different ways, such as international assets, international liabilities and international financial leverage (Bedford, 2008). Exposure to prior crises and market malfunctions provide some guidance as to how companies could equip themselves in order to face these situations. Berle and Means (1932) were the primary researchers to start talking about establishment of a more powerful company. Establishing a powerful company that has the ability to protect its shareholders' wealth is still a challenging issue in academic environments and practical environments (Chareonwong, 2011; Margaritis, 2010). Berle and Means (1932) believe that a diffused ownership structure in a modern corporation allows managers to take control of the company and care less about shareholder wealth. While Berle and Means point out the divergence of interests between managers and owners as the source of problems, further studies in recent years mention separation of ownership and control as being a problem and part of a wider debate about corporate governance (Chen, 2009; International Corporate Governance Network, 2009). As insiders, managers and directors of a company have control over almost all parts of a company, so it is more probable they will be interested in maximizing their own interests which is sometimes in line with owners' utility and sometimes not. Thus, in dealing with corporate governance debates the main issue is to find the mechanisms that utilize the managers' behaviour in value-maximising decisions. Through these mechanisms, owners are able to monitor managers' actions to ensure they are in line with maximising company value.

Mechanisms for utilizing manager behaviour consist of different strategies, such as characteristics of ownership and characteristics for controlling and running the company. The interests of company insiders (managers and directors) and outsiders (investors and shareholders) are highly related to their own benefits. Although moral issues might satisfy insiders to do their best in maximising company value, investors cannot convince themselves to rely on that. Thus, exploring a mechanism for monitoring insiders' behaviour by investors and aligning the interests of insiders and investors seems to be significant. Ownership structure can address these questions by increasing the monitoring power of investors through block ownership and aligning interests through insider ownership (Margaritis, 2010; McConnell, 2008). Bayrakdaroglu, Ersoya and Citak (2012) believe that block ownership is significantly related to a firm's performance but find little evidence of effectiveness for insider ownership.

Although ownership structure plays a significant role in normal business situations, an important issue that companies need to face is whether the same ownership structure can 
survive in companies in difficult and crisis situations. In order to address this question, the global financial crisis of 2007 provides a stunning opportunity. The New Zealand market is a commodity-based economy with relatively small sized companies and affected by its geographical distance to export markets. In comparison, Singapore is a highly international economy with larger companies and an open economy. Therefore, it is appropriate to consider these two different countries and how company ownership structure influences the cost of capital during a financial crisis. Although there are different ownership structures in these two countries, such as higher insider ownership in New Zealand (12\%) compared to relatively lower insider ownership in Singapore (3\%) and lower block ownership in New Zealand (49\%) compared to higher block ownership in Singapore $(72 \%)$, these can be the result of different economy and governance mechanisms and assessing these companies in two different countries will help academics and practitioners to better analyse company and economy situations.

\section{Literature Review}

Conflicts of interest between managers and shareholders have long been studied regarding issues of ownership and performance; the main studies were by Berle and Means (1932) and Jensen and Meckling (1976). Investigations on the relationship between ownership structure and performance of firms go back to (1932) when Berle and Means released the results of their study of US firms. They document that in firms where lots of small shareholders have the ownership of a firm and control of that business is in hands of insider managers, there is a tendency for under performance. Following their study, in (1976) a more classical owner-manager agency problem was developed by Jensen and Meckling. They document that aligning the interests of managers and shareholders is possible by having managers hold shares in that firm. Managers who hold shares in a firm do not have enough incentive to expropriate shareholders' wealth and nor do they engage in external activities that damage company profit. Mehran (1995) in his study on the US market reports a positive linear relationship between managerial ownership and firm performance. In line with these studies, Shleifer and Vishny (1986) indicate that large equity holders have strong incentives to monitor manager performance and that consequently mitigates agency conflicts. Prowse (1994) also indicates that concentrated ownership in companies will mitigate agency problems and agency costs. Demsetz (1983) believes that there is a negative relationship between managerial ownership and companies' financial performance because of the entrenchment effect. Thus, Demsetz documents a negative linear relationship between managerial ownership and financial performance. Ang, Cole and Lin (2000) document a negative relationship between proportions of shares owned by managers and financial performance in the US market. In subsequent years, researchers document no statistical significant relationship between ownership structure and firm performance (Al Farooque, 2007; Demsetz, 2001).

Followed by Demsetz in 1983, Stulz (1988) and Morck et al (1988) document a combined effect of incentive alignment and entrenchment to report the relationship between insider ownership and firm performance. Block holders have strong incentives to monitor and discipline management in order to mitigate agency conflicts (Shleifer, 1986, 1997). 
Entrenchment effect determines whether firm value would be maximised by the presence of large external shareholders (Claessens, 2003; Villalonga, 2006). In this regard, family firms are a special class of large shareholders with unique incentive structures. For example, some factors such as concerns over family and firm reputation can mitigate the agency cost (Anderson, 2003). Minority shareholders' expropriation may still happen in firms with controlling family shareholders (Villalonga, 2006). Reddy et al (2008) find a negative relationship between insider ownership and financial performance in New Zealand small cap companies.

Morck, Shleifer and Vishny (1988) present two conflicting effects for insider ownership: (1) an alignment effect, (2) an entrenchment effect. Alignment effect refers to the positive effect of increasing insider ownership and firm performance by aligning the financial interests of insiders and firm. Entrenchment effect is when the likelihood of replacement through a proxy fight or takeover declines as insider ownership increases and provides more incentives for managers to pursue their own goals. Entrenchment effect shows that expropriation of minority shareholders will occur when managers fail to align managers and shareholder interests by giving shares to managers (Johnson, Boone and Breach 2000, Shleifer and Vishny 1997).

Grossman and Hart (1982) document the strong incentive of external block owners to control the opportunistic behaviour of management. Aside from the positive role block owners have on firm performance because of strong monitoring incentives and voting control, some issues also exist that prevent block owners doing their best for the firm. Cable and Yasuki (1985) document a positive relationship between ownership concentration and firm performance in Japanese firms except keiretsus which is one kind of Japanese company, while Prowse (1992) finds no significant relationship between ownership concentration and financial performance of Japanese firms either keiretsus or non-keiretsus. In contrast, McConnell and Servaes (1990) and Thomsen and Pedersen (2000) show a positive relation between performance and ownership concentration.

Mudambi and Nicosia (1998) in the UK and Lehmann and Weigand (2000) in Germany indicate a negative linear relationship between ownership concentration and firm performance. They believe that expropriation behaviour of block owners negatively affects firm performance, because block owners try to have benefits on minority shareholders' costs. One of the outcomes of this behaviour is that minority shareholders reduce their ownership. Gedajlovic and Shapiro (1998) in US and Miguel, Pindado and La Torre (2004) in Spain predict a quadratic relationship between performance and ownership concentration. They assume that at primary levels of ownership concentration, the positive effect of block owner monitoring leads to an increase in firm performance and improve cost of capital. But in high levels of block ownership the expropriation effect (entrenchment effect) negatively affects their performance and consequently causes a decrease in firm value (Claessens, 2003). Mahrt-Smith (2005) concludes that predicting the effect of ownership structure on firm performance will be difficult unless one controls the firm's capital structure choice. 
Some other studies document a non-linear relationship between ownership concentration and firm performance. They find a cubic relationship which is an up/down/up relationship between performance and ownership concentration (Gugler, 2004; Short, 1999). Gugler, Mueller and Yurtoglu (2004) show that with primary levels of block ownership there is a positive relationship between block ownership and firm performance because of block owners' incentives to monitor managers and their performance. But after a specific level of ownership expropriation, behaviour of block ownership (entrenchment effect) influences their performance and negatively affects firm performance. This happens because their ownership is not up to a level that makes them highly concerned about firm performance and nor is it up to a level where they can have their effect cheaply. In high levels of block ownership there is a positive relationship between block ownership and performance. In this situation they have more incentive to monitor firm performance because their wealth is highly tied with firm performance so they accept the costs of monitoring in order to protect their wealth. Gugler, Mueller and Yurtoglu (2008) document an unclear effect of insider ownership on firm performance. They believe on both positive role of alignment effect and negative role of entrenchment effect.

While prior studies document mixed and inconclusive results on the role of ownership structure, firm performance and cost of capital, it is still challenging to know whether or not this pool of research can address the primary question. The primary question in this field is to know whether ownership structure affects the performance of the firms and if the answer is yes, how does ownership structure affect firms. Although the characteristics of capital markets and the characteristics of each economy require different strategies and guidelines, an empirical study on this issue can clarify different dimensions and aspects of ownership structure. The financial crisis in 2007 provides a unique situation to check the efficiency of academic and practical guidelines on required ownership structure in firms. If research finds that firms in different economies, which implement different ownership structure guidelines, successfully pass through a financial crisis, then it is possible to conclude that the suggested ownership structures are efficient. New Zealand as a commodity-based economy with a unique geographical situation and Singapore as a highly international economy can reflect the idea of various effects of ownership structure in crisis situation in different markets.

\section{Method and Data Description}

This study includes two null hypotheses which are reported below:

H0: Does insider ownership negatively affect cost of capital during global financial crisis

H0: Does block ownership negatively affect cost of capital during global financial crisis

This study employs regression models in order to address the above hypotheses. Panel regression model and ordinary least square (OLS) methods of estimation are employed in this study. As mentioned in the previous section, some studies report a linear relationship between ownership structure (Reddy, 2008), performance and cost of capital while others report a square relationship and yet others report a cubic relationship (Gugler, 2008). Thus in order to 
track the correct relationship between ownership structure and cost of capital, three potential equations are employed.

a. A linear equation to check linear relationship

$(\text { Cost of Capital })_{\text {it }}=\alpha_{\mathrm{i}}+\alpha_{2 \mathrm{i}}$ (Ownership structure $)_{\text {it }}+\alpha_{3 \mathrm{i}}$ Firm size $_{\text {it }}+\alpha_{4 \mathrm{i}}$ Leverage $_{\text {it }}+\alpha_{5} \mathrm{GDP}_{\mathrm{t}}$

b. A square equation to check square relationship

$(\text { Cost of Capital })_{\text {it }}=\alpha_{\mathrm{i}}+\alpha_{2 \mathrm{i}}(\text { Ownership structure })_{\text {it }}+\alpha_{3 \mathrm{i}}(\text { Ownership Structure })_{\text {it }}{ }^{\wedge^{2}}+\alpha_{4 \mathrm{i}}$ Firm size $_{\text {it }}+\alpha_{5 \mathrm{i}}$ Leverage $_{\text {it }}+\alpha_{6} \mathrm{GDP}_{\mathrm{t}}$

c. A cube equation to check cubic relationship

$\left(\right.$ Cost of Capital) it $=\alpha_{i}+\alpha_{2 \mathrm{i}}(\text { Ownership structure })_{\text {it }}+\alpha_{3 \mathrm{i}}(\text { Ownership Structure })_{\text {it }} \wedge^{2}+\alpha_{4 \mathrm{i}}$

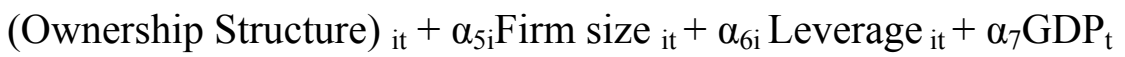

Where ownership structure represents insider ownership or block ownership. Firm size, leverage and GDP are employed as control variables. Insider ownership considers the percentage of the company owned by company managers. Although different definitions exist when estimating block ownership in companies, the most popular method is to calculate the percentage of shares owned by the top five big shareholders. This study also employs the percentage of shares owned by the top five shareholders. These three equations will be used to check the potential relationship between ownership structure (insider ownership and block ownership) and cost of capital. A dummy variable is employed to track the effect of the global financial crisis. These dummy variables will target 2008 individually, and 2009 and 2010 together, to track the role of ownership structure on cost of capital during and after the global financial crisis.

Different models of calculating cost of capital have been developed in prior studies. Among these methods, weighted average cost of capital captures the effect of cost of equity and cost of debt together. Weighted average cost of capital (WACC) is obtained from Modigliani and Miller (1958, 1963) and Miles and Ezzell (1980) studies. Ross, Westerfield and Jaffe (1996) argue that WACC is the most widely used method of calculating cost of capital in the real world so far. Basic definition of WACC, which is the cost of capital coming from both equity and debt, make it one of the fundamental concepts in corporate finance (Farber, 2006).

WACC equation for a firm which is using common share (equity) and bond (debt) financing is as below:

$\mathrm{WACC}=r=w_{d} r_{d}(1-t)+w_{e} r_{e}$

Where $r_{d}$ represents the market rate on the firm's outstanding debt as cost of debt and $r_{e}$ represents cost of equity which is frequently calculated by CAPM method. $W_{d}$ is the weights of debt and $\mathrm{w}_{\mathrm{e}}$ is the weights of equity and $\mathrm{t}$ is tax. The most challenging part of this equation is the method of estimating cost of equity. The primary method of calculating cost of equity was implemented by Sharpe (1964) and Lintner (1965). They believe that fluctuation of market price can reflect the behaviour of a company's price completely. So they document the fluctuation of company price as the side effect of fluctuation of market price. They called 


\section{Macrothink}

their model Capital Asset Pricing Model (CAPM). CAPM was the unique method of estimating cost of equity since Fama and French (1992) revealed the result of their study and introduced two other explanatory variables for explaining market price behaviour. Their Fama-French Three Factor model, which includes firm size and book-to-market equity of companies, was the popular method of calculating cost of equity while Jegadeesh and Titman (1993) and Fama and French (1993) revealed their comments about the effectiveness of another factor (momentum factor) on fluctuation of companies. Their momentum effect was the return of diversified portfolio of winners minus losers. Although negative and positive comments exist in employing each method, most recent studies suggest the momentum model is a better model for estimating cost of equity (Fama, 2004; Tien, 2010).

\section{Data}

Data from large listed companies on the New Zealand Stock Exchange (NZX) and Singapore Exchange Market (SGX) during 2006 to 2010 are employed in this study. Large listed companies in New Zealand and Singapore are collected through NZX 50 and STI Constituent respectively. The Thomson One Banker database and DataStream are employed to extract the data for weighted average cost of capital and firm size in New Zealand's listed companies and Singapore's listed companies during 2006 to 2010. The ownership information of companies consists of insider ownership and block ownership collected from the annual reports of each listed company.

Some companies are omitted from the sample because of unreported or insufficient data or unreported annual reports. The nature and characteristics of the New Zealand market, which make it more unique, cause more elimination. It is obvious that in small markets like New Zealand, not all the companies have transactions every day. Thus, it is expectable to lose a higher number of companies in New Zealand. Descriptive statistics of this study are reported in table 1 as below: 
Table 1. Descriptive statistics

\begin{tabular}{|l|c|c|c|c|c|c|c|c|c|c|}
\hline & Insider & Block & Firm & & & Insider & Block & & & \\
& Own. & Own. & Size & LEVERAGE & GDP & Own. & Own. & Firm Size & LEVERAGE & GDP \\
\hline Mean & 8.21 & 48.68 & 13.25 & 2.27 & 1.02 & 1.88 & 71.87 & 15.80 & 2.54 & (NZ) \\
\hline Median & 1.1 & 48.26 & 13.23 & 0.93 & 1.3 & 0.13 & 75.37 & 15.78 & 0.87 & (NZ) \\
\hline Maximum & 65.00 & 89.02 & 15.99 & 51.29 & 2.7 & 27.8 & 93.23 & 17.97 & 32.20 & 14.80 \\
\hline Minimum & 0.00 & 0.41 & 8.57 & 0.12 & -2.1 & 0.00 & 39.39 & 12.09 & -2.8 & -1.00 \\
\hline Std. Dev. & 13.8 & 20.44 & 1.26 & 6.21 & 1.78 & 6.2 & 14.47 & 1.00 & 4.11 & 5.66 \\
\hline Skewness & 2.21 & 0.02 & -0.48 & 5.89 & -0.75 & 3.49 & -0.52 & -0.58 & 3.67 & 0.00 \\
\hline Kurtosis & 8.11 & 2.44 & 3.58 & 38.64 & 2.24 & 13.59 & 2.07 & 4.59 & 22.50 & 1.68 \\
\hline Observations & 195 & 195 & 195 & 195 & 195 & 135 & 135 & 135 & 135 & 135 \\
\hline
\end{tabular}

As discussed in the previous section, the New Zealand market is a relatively small market. The average firm size of New Zealand's large listed firms is smaller than firm size of Singapore's large listed firms. Block ownership in New Zealand's large listed companies is 49 per cent while in Singapore 72 per cent of firm ownership belongs to the top five shareholders. Although block ownership in Singapore is significantly higher than New Zealand, percentage of shares owned by managers of companies in New Zealand is 8.21 per cent which is much higher than 1.88 per cent in Singapore. Thus, it is expectable to track different roles for ownership structure on cost of capital in New Zealand and Singapore.

High standard deviation and difference between mean and median of some variables show that the distributions of these variables are not normal. Along with high standard deviation, skewness of variables, which is reported in descriptive statistics shows that variables have tails on their right or left hand side. High kurtosis distribution, which report in some variables, shows that the distribution of these variables has a sharper peak and longer fat tails. Dealing with unbalanced data requires some consideration. Exclusion of outliers in case of presence of fat tails may lead to depriving the estimations of some effective variables. In order to prevent excluding important variables in fat tails the Grubbs test is implemented in this study. The difference between true outliers and outliers in fat tails that contain important 
information is detectable through the Grubbs test. Implementation of this test reveals two real outliers in insider ownership variables. These variables are corrected by reconsidering the databases. Thus, presence of high standard deviation beside skewness and Kurtosis distribution of data in this study does not lead to exclusion of data because the Grubbs test reveals the importance of data in fat tails.

Endogeneity, heteroskedasticity and correlation of variables have been checked and a weighted coefficient covariance method is employed to track all three. This happens in insider ownership of the Singapore market.

\section{Empirical Results}

Empirical results of this study document a cubic relationship between block ownership and cost of capital in New Zealand, whereas the relationship between block ownership and cost of capital in Singapore is squared. The cube relationship in New Zealand is like a down/up/down relationship, the squared relationship in Singapore is like up/down relationship. In New Zealand, an increase in block ownership up to 18.52 per cent causes cost of capital to decline, while increasing block ownership between 18.52 per cent and 60.86 per cent causes cost of capital to increase. However, increasing block ownership over 60.86 per cent leads to a decline in the cost of capital again. This means that at low levels of block ownership leads to interest alignment between the shareholders and the management. However, when block ownership increases between $18.52 \%$ and $60.86 \%$, it leads to an entrenchment effect causing cost of capital to increase. At higher levels of block ownership, the interest alignment effect causes cost of capital to decline again.

The relationship between block ownership and cost of capital in Singapore is an up/down relationship where an increase in block ownership up to 67.43 per cent increases the cost of capital and block ownership over 67.43 per cent causes cost of capital to decline. This means that block ownership up to $67.43 \%$ has a negative effect on cost of capital in Singapore because of the entrenchment and expropriation behaviour. However, the block ownership over $67.43 \%$ leads to an interest alignment causing cost of capital to decline.

However, empirical results provide a different picture when we consider year-dummy variables for 2008 and for 2009 -2010. The results for the year-dummy for 2008 show a negative relationship between block ownership and cost of capital and the year-dummies for 2009 and 2010 document a positive relationship in New Zealand. In Singapore the year-dummy variable for 2008 show a statistically significantly positive relationship while the year dummy variable for after-2008 show a positive but statistically insignificant relationship. The results show that, block owners negatively affected cost of capital in New Zealand during 2008 and in the years after 2008, the role of block ownership on cost of capital is positive because of expropriation behaviour.

Our results show that block ownership in the Singapore market positively affects cost of capital during and after a financial crisis while this effect is statistically significant in 2008 but not after 2008. This indicates that high level of block ownership has been ineffective in Singapore after the financial crisis period. However, during financial crisis period a high 
block ownership has had a negative effect cost of capital. The average level of block ownership in New Zealand and Singapore are $49 \%$ and $72 \%$ respectively.

Our empirical results documents a cube relationship between insider ownership and cost of capital in New Zealand and a linear relationship between insider ownership and cost of capital in Singapore. The cube relationship in New Zealand is like an up/down/up relationship while in Singapore, the linear relationship shows a negative relationship. In New Zealand, an increase in insider ownership up to 13.16 per cent causes an increase in cost of capital while increasing the insider ownership between 13.16 per cent and 50.63 per cent leads to an increase in the cost of capital. However, increasing insider ownership in New Zealand over 50.63 per cent leads to an increase in the cost of capital again. Our results indicate that at low level of insider ownership, leads to value-destroying decisions. Insider ownership between $13.16 \%$ and $50.63 \%$, negatively affects cost of capital because of the interest alignment of the principals and the agents. Insider ownership over $50.63 \%$ positively affects the cost of capital because of the entrenchment effect and the expropriation behaviour of insiders.

The relationship between insider ownership and cost of capital in Singapore is negative which indicates that an increase in insider ownership decreases the cost of capital. This means that higher levels of insider ownership tend to better align the interests of insiders and firm. As the average level of insider ownership in Singapore is $1.88 \%$, which is not relatively high, a higher level of insider ownership makes the insiders more concerned about maximising firm value.

The empirical results relating to the year-dummy variables for 2008 and the period 2009 2010 reveal different results for the insider ownership. While the year dummy for 2008 show a negative relationship between insider ownership and cost of capital, the year dummies for 2009 and 2010 document a positive relationship in both, New Zealand and Singapore. Insider ownership positively affects cost of capital in Singapore but this effect is not statistically significant. The average level of insider ownership in New Zealand is 8.21Our results show that there is a positive effect of insider ownership on cost of capital in years after 2008 but have a negative effect cost of capital e during 2008. This indicates that the current level of insider ownership has a positive effect on companies in New Zealand. In Singapore, our results show that insider ownership has a positive effect on cost of capital of companies during and after a financial crisis. This indicates that the insider ownership structure in Singapore is not at optimal and has a negative effect on the cost of capital in Singapore. Estimations of this study are reported in appendix A and B.

\section{Conclusion}

This paper investigates the effect of ownership structure on cost of capital during and after the 2007 global financial crisis in New Zealand and Singapore's large listed companies. Although the results of prior studies about the effect of ownership structure on firms were mixed and inconclusive, this study finds interesting results regarding the ownership-performance relationship. Despite the ordinary effect of ownership structure on cost of capital (which depends on the pattern of their relationship between ownership and cost 
of capital and the position of a firm's ownership), the role of ownership structure on cost of capital affects the cost of capital differently during a crisis and after the crisis. Our results show that block ownership in New Zealand has a cubic relationship with cost of capital. We also report that the block ownership in New Zealand has had a negative effect on cost of capital during financial crisis which reflects on the effectiveness of block ownership in monitoring managerial decisions during the financial crisis period. However, the effect of block ownership of cost of capital becomes ineffective after the financial crisis period. However, block ownership in Singapore has a positive effect on cost of capital during and after a financial crisis, thus indicates that block owners in Singapore were not interested in monitoring managerial decisions in the companies they own.

The empirical results for insider ownership in New Zealand are very for the block ownership. There is cubic relationship between insider ownership and cost of capital in New Zealand. Our results show that during a financial crisis, insider ownership has had a negative effect on the cost of capital. However, our results show that the insider ownership in Singapore has had a negative relationship with cost of capital. Our results indicate that insider ownership level in Singapore is not at an optimal level.

In summary, our results indicate that of the current ownership structure has helped companies in New Zealand assists protection from the effect of the global financial crisis.. The level of insider ownership and relatively high level of block ownership in Singapore reflects the view that ownership structure is Singapore is not at an optimal level.

\section{References}

Al Farooque, O., Zijl, T. V., Dunstan, K., Karim, AKM. W.,. (2007). Ownership structure and corporate performance: evidence from Bangladesh. Asia-Pacific Journal of Accounting \& Economics, 14, 127-150. http://dx.doi.org/10.1080/16081625.2007.9720792

Anderson, R. C., Reeb, D.M.,. (2003). Founding family ownership, corporate diversification, and firm leverage. Journal of Law and Economics, 46, 653-684. http://dx.doi.org/10.1086/377115

Ang, J. S., Cole, R. A., Lin, J. W. (2000). Agency costs and ownership structure. The Journal of Finance(1), 81-106. http://dx.doi.org/10.1111/0022-1082.00201

Bayrakdaroglu, A., Ersoy, E., Citak, L.,. (2012). Is there a relationship between corporate governance and value-based financial performance measures? A study of Turkey as an emerging market. Asia-Pacific Journal of Financial Studies, 41, 224-239. http://dx.doi.org/10.1111/j.2041-6156.2012.01071.x

Bedford, P. (2008). The global Financial Crisis and its transmission to New Zealand - an external balance sheet analysis. Reserve Bank of New Zealand, 71(4), 18-28.

Berle, A. A., and G. Means,. (1932). The modern Corporation and Private Property. Macmillan Press, New York 
Cable, J., Yasuki, H.,. (1985). Internal organization, business groups and corporate performance: an empirical test of the multi-divisional hypothesis in Japan. International Journal of Industrial Organization, $3, \quad 301-420$. http://dx.doi.org/10.1016/0167-7187(85)90032-3

Chareonwong, C., Ding, D. K., Siraprapasiri, V.,. (2011). Adverse selection and corporate governance. International Review of Economics and Finance, 20, 406-420. http://dx.doi.org/10.1016/j.iref.2010.11.011

Chen, K., Chen, Z., Wei, J.,. (2009). Legal protection of investors, corporate governance, and the cost of equity capital. Journal of Corporate Finance, 15, 273-289. http://dx.doi.org/10.1016/j.jcorpfin.2009.01.001

Claessens, S., Djankov, S., Fan, J., Lang, L. (2003). Disentangling the incentive and entrenchment effects of large shareholdings. Journal of Finance, 57(6), 2741-2771. http://dx.doi.org/10.1111/1540-6261.00511

De Miguel, A., Pindado, J., De La Torre, C.,. (2004). Owneship structure and firm value: new evidence form Spain. Strategic Management Journal, 25(12), 1199-1207. http://dx.doi.org/10.1002/smj.430

Demsetz, H., Villalonga, B.,. (1983). The structure of ownership and the theory of the firm. Journal of Law and Economics, 26, 375-390. http://dx.doi.org/10.1002/smj.430

Demsetz, H., Villalonga, B.,. (2001). Ownership structure and corporate performance. $\begin{array}{lllll}\text { Journal of } & \text { Corporate } & \text { Finance, } & 7, & \text { 209-234. }\end{array}$ http://dx.doi.org/10.1016/S0929-1199(01)00020-7

Fama, E. F., French, K.R.,. (1992). The cross-section of expected stock returns. Journal of Finance, 47, 427-465. http://dx.doi.org/10.1111/j.1540-6261.1992.tb04398.x

Fama, E. F., French, K.R.,. (1993). Common risk factors in returns on stocks and bonds. Journal of Financial Economics, 33, 3-56. http://dx.doi.org/10.1016/0304-405X(93)90023-5

Fama, E. F., French, R.F.,. (2004). The Capital Asset Pricing Model: Theory and Evidence. $\begin{array}{llll}\text { Journal of } \quad \text { Economic } & \text { 25-46. }\end{array}$ http://dx.doi.org/10.1257/0895330042162430

Farber, A., Gillet, R., Szafarz, A.,. (2006). A general formula for the WACC. International Journal of Business, 11(2), 211-218.

Gedajlovic, E., Shapiro, D.,. (1998). Management and ownership effects: evidence from five countries. Strategic Management Journal, 19(6), 533-553. http://dx.doi.org/10.1002/(SICI)1097-0266(199806)19:6<533::AID-SMJ957>3.0.CO;2-\#

Grossman, S. J., Hart, O.,. (1982). Corporate financial structure and managerial incentives. In: McCall, J. (Ed.), The Economics of Information and Uncertainty(University of Chicago Press, Chicago) 
Gugler, K., Mueller, D.C., Yurtoglu, B.B.,. (2004). Corporate governance and the returns on investment. Journal of Law and Economics, 47, 589-633. http://dx.doi.org/10.1086/425062

Gugler, K., Mueller, D.C., Yurtoglu, B.B.,. (2008). Insider ownership, ownership concentration and investment performance: An international comparison. Journal of Corporate Finance, 14, 688-705. http://dx.doi.org/10.1016/j.jcorpfin.2008.09.007

International Corporate Governance Network. (2009. ICGN Global Corporate Governance Principles: Revised (2009). Paper presented at the ICGN Conference, Washington, USA.

Jegadeesh, N., Titman, S,. (1993). Returns to buying winners and selling losers: Implications for stock market efficiency Journal of Finance, 48(1), 65-91. http://dx.doi.org/10.1111/j.1540-6261.1993.tb04702.x

Jensen, M. C., Meckling, W. H.,. (1976). Theory of the firm: managerial behavior, agency costs and ownership structure. Journal of Financial Economics, 3, 305-360. http://dx.doi.org/10.1016/0304-405X(76)90026-X

Lehmann, E., Weigand, J.,. (2000). Does the governed corporation perform better? Governance structures and corporate performance in Germany. European Finance Review, 4, 157-195. http://dx.doi.org/10.1023/A:1009896709767

Lintner, J. (1965). The valuation of risk assets and the selection of risky investments in stock portfolios and capital budgets. Review of Economics and Statistics, 47(1), 13-37. http://dx.doi.org/10.2307/1924119

Mahrt-Smith, J. (2005). The interaction of capital structure and ownership structure. Journal of Business, 78, 787-816. http://dx.doi.org/10.1086/429644

Margaritis, D., Psillaki, M.,. (2010). Capital structure, equity ownership and firm performance. Journal of Banking \& Finance, 34, 621-632. http://dx.doi.org/10.1016/j.jbankfin.2009.08.023

McConnell, J. J., Servaes, H.,. (1990). Additional evidence on equity ownership and corporate value. Journal of Financial Economics, 27, 595-612. http://dx.doi.org/10.1016/0304-405X(90)90069-C

McConnell, J. J., Servaes, H., Lins, K. V., . (2008). Changes in insider ownership and changes in the market value of the firm. Journal of Corporate Finance, 14, 92-106. http://dx.doi.org/10.1016/j.jcorpfin.2008.02.001

Mehran, H. (1995). Executive compensation, ownership, and firm performance. Journal of Financial Economics, 38(2), 163-184. http://dx.doi.org/10.1016/0304-405X(94)00809-F

Miles, J. A., Ezzell, J. R.,. (1980). The weighted average cost of capital, perfect capital markets, and project life: A clarification. Journal of Financial and Quantitative Analysis, 15, 719-730. http://dx.doi.org/10.2307/2330405

Modigliani, F., Miller, M. H.,. (1958). The cost of capital, corporation finance and the theory of investment. American Economic Review, 48, 261-297. 
Modigliani, F., Miller, M. H.,. (1963). Corporate income taxes and cost of capital. American Economic Review, 53, 433-443.

Morck, R., Shleifer, A., R.W.Vishny,. (1988). Management ownership and market valuation: an empirical analysis Journal of Financial Economics, 20, 293-315. http://dx.doi.org/10.1016/0304-405X(88)90048-7

Mudambi, R., Nicosia, C.,. (1998). Ownership structure and firm performance: evidence from the U.K. financial services industry. Applied Financial Economics, 8, 175-180. http://dx.doi.org/10.1080/096031098333159

Prowse, S. (1992). The structure of corporate ownership in Japan. Journal of Finance, 47, 1121-1140. http://dx.doi.org/10.1111/j.1540-6261.1992.tb04007.x

Reddy, K., Locke, S. M., Scrimgeour, F. G., Gunasekarage, A. (2008). Corporate governance practices of small cap companies and their financial performance: an empirical study in New Zealand. International Journal of Business Governance and Ethics, 1(4), 51-78. http://dx.doi.org/10.1504/IJBGE.2008.017891

Ross, S. A., Westerfield, R. W., Jaffe, J. F.,. (1996). Corporate finance: Chicago: McGraw-Hill, Inc.

Sharpe, W. F. (1964). Capital asset prices: a theory of market equilibrium under conditions of risk. Journal of Finance, 19(3), 425-442.

Shleifer, A., and R. W. Vishny,. (1986). Large shareholders and corporate control. Journal of Political Economy, 94, 461-488. http://dx.doi.org/10.1086/261385

Shleifer, A., and R. W. Vishny,. (1997). A survey of corporate governance. Journal of Finance, 52(2), 737-783. http://dx.doi.org/10.1086/261385

Short, H., Keasey, K.,. (1999). Managerial ownership and performance of firms: evidence from the UK. Journal of Corporate Finance, 5, 79-101. http://dx.doi.org/10.1086/261385

Stulz, R. (1988). Managerial control of voting rights: financing policies and the market for corporate control. Journal of Financial Economics, 20, 25-59. http://dx.doi.org/10.1016/0304-405X(88)90039-6

The World Bank. (2010). Global economic prospects. Washington

Thomsen, S., Pedersen, T.,. (2000). Ownership structure and economic performance in the largest European companies. Strategic Management Journal, 21, 689-705. http://dx.doi.org/10.1002/(SICI)1097-0266(200006)21:6<689::AID-SMJ115>3.0.CO;2-Y

Tien, J. J., Wang, j. L.,. (2010. The momentum effect on estimating the cost of equity capital for property-liability insurers. Paper presented at the NTU International Conference of Finance, National Taiwan University.

Villalonga, B., Amit, R.,. (2006). How do family ownership, control and management affect firm value? Journal of Financial Economics, 80, 385-417. 
Appendix A. Estimating the Effect of Ownership Structure on Cost of Capital (During and After Global Financial Crisis) in New Zealand

Block ownership and cost of capital in New Zealand in 2008

Dependent Variable: WACC

Method: Pooled Least Squares

Total pool (balanced) observations: 195

\begin{tabular}{crcrc}
\hline \multicolumn{1}{c}{ Variable } & Coefficient & Std. Error & t-Statistic & Prob. \\
\hline C & 8.271672 & 0.604399 & 13.68578 & 0.0000 \\
Large & -8.650723 & 3.597196 & -2.404852 & 0.0172 \\
Large`2 & 30.15846 & 10.41633 & 2.895307 & 0.0042 \\
Large`3 & -25.26902 & 8.050133 & -3.138956 & 0.0020 \\
LN(Size) & -0.067641 & 0.060706 & -1.114225 & 0.2666 \\
LEVERAGE & -0.203825 & 0.023540 & -8.658570 & 0.0000 \\
\multicolumn{1}{c}{ GDP } & -0.006295 & 0.028042 & -0.224500 & 0.8226 \\
\multicolumn{1}{c}{ DUMMY(2008) } & -0.518033 & 0.051671 & -10.02569 & 0.0000 \\
\hline R-squared & 0.282452 & Mean dependent var & 6.540259 \\
Adjusted R-squared & 0.255592 & S.D. dependent var & 2.526082 \\
S.E. of regression & 2.179480 & Akaike info criterion & 4.436210 \\
Sum squared resid & 888.2747 & Schwarz criterion & 4.570487 \\
Log likelihood & -424.5305 & Hannan-Quinn criter. & 4.490577 \\
F-statistic & 10.51570 & Durbin-Watson stat & 0.604093 \\
Prob(F-statistic) & 0.000000 & & \\
\hline
\end{tabular}




\section{Macrothink}

Block ownership and cost of capital in New Zealand after 2008

Dependent Variable: WACC

Method: Pooled Least Squares

Total pool (balanced) observations: 195

\begin{tabular}{lrcrr}
\hline \hline \multicolumn{1}{c}{ Variable } & Coefficient & Std. Error & t-Statistic & Prob. \\
\hline \hline C & 7.928905 & 0.723338 & 10.96154 & 0.0000 \\
Large & -8.842967 & 3.622949 & -2.440820 & 0.0156 \\
Large`2 & 30.73964 & 10.48238 & 2.932507 & 0.0038 \\
Large 3 & -25.64114 & 8.109621 & -3.161817 & 0.0018 \\
\multicolumn{1}{c}{ LN(Size) } & -0.086868 & 0.067592 & -1.285189 & 0.2003 \\
\multicolumn{1}{c}{ LEVERAGE } & -0.203664 & 0.023504 & -8.665246 & 0.0000 \\
\multicolumn{1}{c}{ GDP } & 0.166648 & 0.045054 & 3.698848 & 0.0003 \\
DUMMY(2009,2010) & 0.785978 & 0.181020 & 4.341929 & 0.0000 \\
\hline \hline R-squared & 0.282723 & Mean dependent var & 6.540259 \\
Adjusted R-squared & 0.255873 & S.D. dependent var & & 2.526082 \\
S.E. of regression & 2.179068 & Akaike info criterion & 4.435832 \\
Sum squared resid & 887.9394 & Schwarz criterion & 4.570109 \\
Log likelihood & -424.4936 & Hannan-Quinn criter. & 4.490199 \\
F-statistic & 10.52976 & Durbin-Watson stat & 0.603153 \\
Prob(F-statistic) & 0.000000 & & \\
\hline \hline & & & \\
\hline
\end{tabular}


Insider ownership and cost of capital in New Zealand in 2008

Dependent Variable: WACC

Method: Pooled Least Squares

Total pool (balanced) observations: 195

\begin{tabular}{lrcrr}
\hline \multicolumn{1}{c}{ Variable } & Coefficient & Std. Error & t-Statistic & Prob. \\
\hline \hline C & 5.355533 & 0.954685 & 5.609738 & 0.0000 \\
Insider & 22.52175 & 4.500250 & 5.004556 & 0.0000 \\
Insider`2 & -107.4656 & 19.84272 & -5.415872 & 0.0000 \\
\multicolumn{1}{c}{ Insider`3 } & 112.3925 & 21.78575 & 5.158990 & 0.0000 \\
\multicolumn{1}{c}{ LN(Size) } & 0.106050 & 0.064117 & 1.654008 & 0.0998 \\
LEVERAGE & -0.191965 & 0.021828 & -8.794347 & 0.0000 \\
\multicolumn{1}{c}{ GDP } & 0.010362 & 0.022427 & 0.462038 & 0.6446 \\
DUMMY(2008) & -0.602786 & 0.038690 & -15.57982 & 0.0000 \\
\hline \hline R-squared & 0.281860 & Mean dependent var & 6.540259 \\
Adjusted R-squared & 0.254978 & S.D. dependent var & & 2.526082 \\
S.E. of regression & 2.180379 & Akaike info criterion & 4.437035 \\
Sum squared resid & 889.0078 & Schwarz criterion & 4.571312 \\
Log likelihood & -424.6109 & Hannan-Quinn criter. & 4.491402 \\
F-statistic & 10.48500 & Durbin-Watson stat & 0.625110 \\
Prob(F-statistic) & 0.000000 & & \\
\hline \hline
\end{tabular}


Insider ownership and cost of capital in New Zealand after 2008

Dependent Variable: WACC

Method: Pooled Least Squares

Total pool (balanced) observations: 195

\begin{tabular}{|c|c|c|c|c|}
\hline Variable & Coefficient & Std. Error & t-Statistic & Prob. \\
\hline $\mathrm{C}$ & 5.184484 & 1.033446 & 5.016695 & 0.0000 \\
\hline Insider & 21.05293 & 4.693327 & 4.485716 & 0.0000 \\
\hline Insider ${ }^{\wedge} 2$ & -100.8021 & 20.61161 & -4.890551 & 0.0000 \\
\hline Insider ${ }^{\wedge}$ & 105.3194 & 22.57381 & 4.665556 & 0.0000 \\
\hline LN(Size) & 0.078334 & 0.070363 & 1.113289 & 0.2670 \\
\hline LEVERAGE & -0.192830 & 0.021996 & -8.766701 & 0.0000 \\
\hline GDP & 0.166066 & 0.070954 & 2.340460 & 0.0203 \\
\hline DUMMY $(2009,2010)$ & 0.720070 & 0.286800 & 2.510706 & 0.0129 \\
\hline R-squared & 0.278719 & \multicolumn{2}{|l|}{ Mean dependent var } & 6.540259 \\
\hline Adjusted R-squared & 0.251719 & \multicolumn{2}{|l|}{ S.D. dependent var } & 2.526082 \\
\hline S.E. of regression & 2.185143 & \multicolumn{2}{|l|}{ Akaike info criterion } & 4.441400 \\
\hline Sum squared resid & 892.8969 & \multicolumn{2}{|l|}{ Schwarz criterion } & 4.575677 \\
\hline Log likelihood & -425.0365 & \multicolumn{2}{|l|}{ Hannan-Quinn criter. } & 4.495767 \\
\hline F-statistic & 10.32297 & \multicolumn{2}{|l|}{ Durbin-Watson stat } & 0.631963 \\
\hline Prob(F-statistic) & 0.000000 & & & \\
\hline
\end{tabular}


Appendix B. Estimating the Effect of Ownership Structure on Cost of Capital (During and After Global Financial Crisis) in Singapore

Block ownership and cost of capital in Singapore in 2008

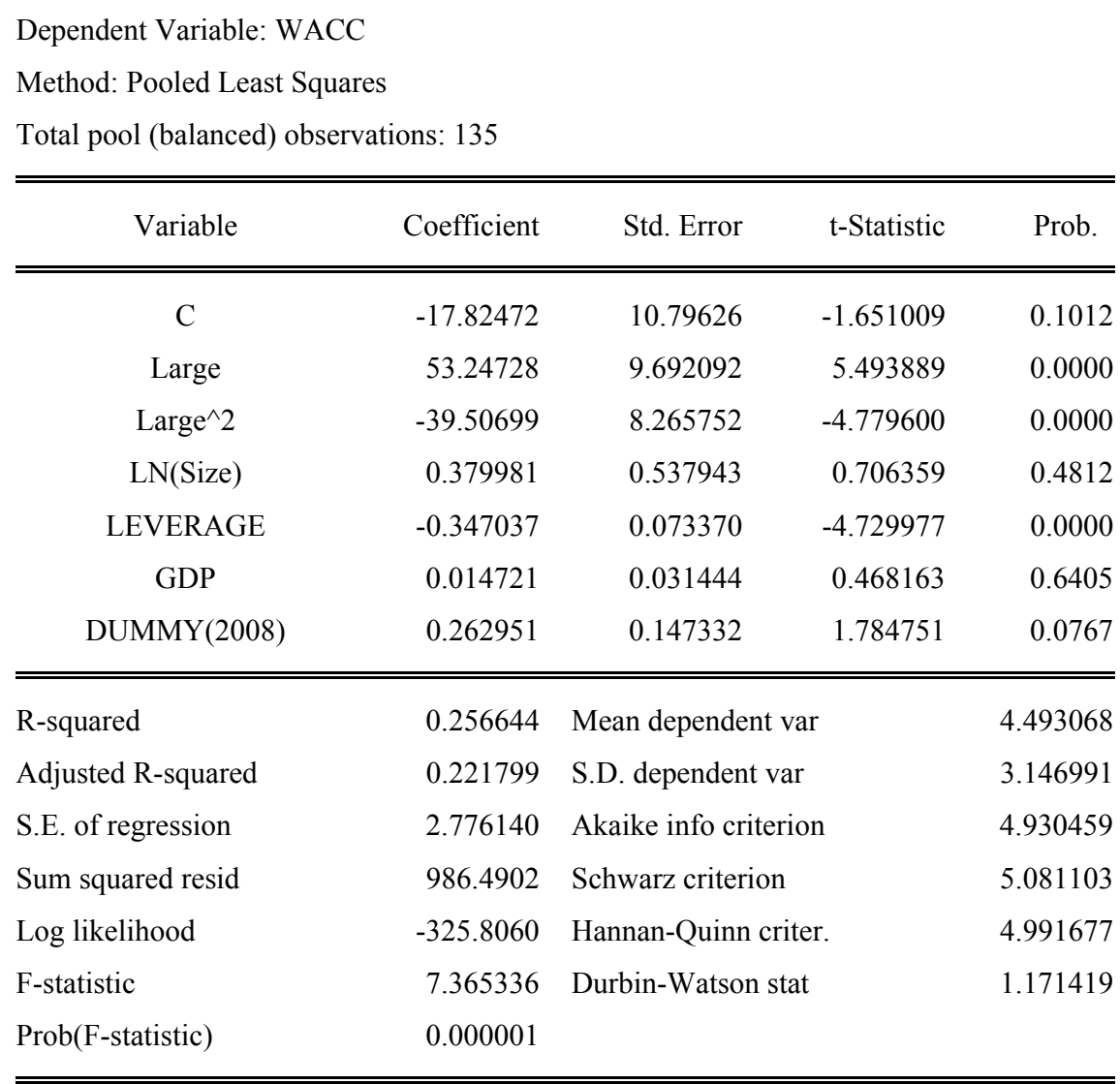




\section{Macrothink}

Block ownership and cost of capital in Singapore after 2008

Dependent Variable: WACC

Method: Pooled Least Squares

Total pool (balanced) observations: 135

\begin{tabular}{lrcrr}
\hline \multicolumn{1}{c}{ Variable } & Coefficient & Std. Error & t-Statistic & Prob. \\
\hline \hline C & -18.09396 & 10.45832 & -1.730102 & 0.0860 \\
Large & 53.08459 & 9.539455 & 5.564741 & 0.0000 \\
Large`2 & -39.33503 & 8.116761 & -4.846149 & 0.0000 \\
LN(Size) & 0.400300 & 0.511353 & 0.782824 & 0.4352 \\
\multicolumn{1}{c}{ LEVERAGE } & -0.346919 & 0.072503 & -4.784910 & 0.0000 \\
\multicolumn{1}{c}{ GDP } & 0.005620 & 0.026438 & 0.212562 & 0.8320 \\
DUMMY(2009,2010) & 0.213434 & 0.351499 & 0.607212 & 0.5448 \\
\hline \hline R-squared & 0.256896 & Mean dependent var & 4.493068 \\
Adjusted R-squared & 0.222063 & S.D. dependent var & & 3.146991 \\
S.E. of regression & 2.775669 & Akaike info criterion & 4.930120 \\
Sum squared resid & 986.1556 & Schwarz criterion & 5.080764 \\
Log likelihood & -325.7831 & Hannan-Quinn criter. & 4.991338 \\
F-statistic & 7.375074 & Durbin-Watson stat & 1.166240 \\
Prob(F-statistic) & 0.000001 & & \\
\hline \hline
\end{tabular}


Insider ownership and cost of capital in Singapore in 2008

Dependent Variable: WACC

Method: Pooled Least Squares

Total pool (balanced) observations: 135

Cross-section weights (PCSE) standard errors \& covariance (d.f. corrected)

\begin{tabular}{lrcrr}
\hline \multicolumn{1}{c}{ Variable } & Coefficient & Std. Error & t-Statistic & Prob. \\
\hline \hline C & -3.375147 & 7.243710 & -0.465942 & 0.6420 \\
Insider & -5.483263 & 3.026795 & -1.811574 & 0.0724 \\
LN(Size) & 0.552969 & 0.468364 & 1.180641 & 0.2399 \\
\multicolumn{1}{c}{ LEVERAGE } & -0.319168 & 0.057806 & -5.521405 & 0.0000 \\
\multicolumn{1}{c}{ GDP } & 0.000975 & 0.051646 & 0.018881 & 0.9850 \\
\multicolumn{1}{c}{ DUMMY(2008) } & 0.175073 & 0.712934 & 0.245568 & 0.8064 \\
\hline \hline R-squared & 0.212498 & Mean dependent var & 4.493068 \\
Adjusted R-squared & 0.181975 & S.D. dependent var & 3.146991 \\
S.E. of regression & 2.846288 & Akaike info criterion & 4.973335 \\
Sum squared resid & 1045.075 & Schwarz criterion & 5.102458 \\
Log likelihood & -329.7001 & Hannan-Quinn criter. & 5.025807 \\
F-statistic & 6.961822 & Durbin-Watson stat & 1.179121 \\
Prob(F-statistic) & 0.000009 & & \\
\hline \hline
\end{tabular}




\section{Macrothink}

Insider ownership and cost of capital in Singapore after 2008

Dependent Variable: WACC

Method: Pooled Least Squares

Total pool (balanced) observations: 135

Cross-section weights (PCSE) standard errors \& covariance (d.f. corrected)

\begin{tabular}{lrcrr}
\hline \multicolumn{1}{c}{ Variable } & Coefficient & Std. Error & t-Statistic & Prob. \\
\hline \hline C & -3.585075 & 7.064813 & -0.507455 & 0.6127 \\
Insider & -5.544249 & 2.865991 & -1.934496 & 0.0552 \\
LN(Size) & 0.564831 & 0.448205 & 1.260206 & 0.2099 \\
\multicolumn{1}{c}{ LEVERAGE } & -0.319479 & 0.056642 & -5.640284 & 0.0000 \\
\multicolumn{1}{c}{ GDP } & -0.005433 & 0.044486 & -0.122130 & 0.9030 \\
DUMMY(2009,2010) & 0.254901 & 0.487671 & 0.522690 & 0.6021 \\
\hline \hline R-squared & 0.213703 & Mean dependent var & 4.493068 \\
Adjusted R-squared & 0.183226 & S.D. dependent var & 3.146991 \\
S.E. of regression & 2.844110 & Akaike info criterion & 4.971804 \\
Sum squared resid & 1043.476 & Schwarz criterion & 5.100927 \\
Log likelihood & -329.5968 & Hannan-Quinn criter. & 5.024276 \\
F-statistic & 7.012025 & Durbin-Watson stat & 1.177156 \\
Prob(F-statistic) & 0.000008 & & \\
\hline \hline
\end{tabular}

